\title{
THE BOLD, THE BEAUTIFUL AND THE BEASTS IN THE BOOK OF DANIEL
}

Hans van Deventer

North-West University

\begin{abstract}
Bodies abound in the book of Daniel. In the very first chapter bold captives refuse defilement of their bodies by foreign food and present "bodies of evidence" to support their case. In the next story history itself finds embodiment in a huge statue. In the two martyr stories (Dan 3 and 6) potentially destructive bodily punishment is envisaged. In Dan 4 the body of a king becomes the body of a beast and in Dan 5 a severed bodily part leads to a king losing control over his bodily functions. In the visionary part of the book (Dan 7-12) empires find embodiment in weird animals, and even the divine being is represented by a (human) body! The book reaches a climax in the last chapter by hinting at a bodily resurrection. This paper addresses the question of what these bodies are "saying" apart from the words uttered by the talking characters to which they "belong." What are the cultural structures that are subverted or reinforced by means of the silently speaking bodies in the book of Daniel?
\end{abstract}

Keywords: Book of Daniel, interpretation, body

\section{Introduction}

There are many angles from which the bodies in the book of Daniel can be investigated. One can, for example, introduce an overarching theory from one of the social sciences and then plot the biblical text under consideration (in this case the book of Daniel) unto that theory. In this way the theory acts as a (hermeneutic) key unlocking possible commonalities and thus giving a certain insight as to how theory and text relate to each other. However, from a post-modern perspective, as presented in a text like The Postmodern Bible seeking (and indeed finding) such a "grand narrative" is understandably frowned at (cf. Bible and Culture Collective 1995, 2-3). The underlying problem is not only the instability of these grand narratives, as post-modern theorists have indicated, but also that data (texts, natural phenomena, human actions) rarely fit into our devised patterns - on the contrary closer analysis quite often will reveal that data resist such attempts (Adam 1995, 10-11).

Another possible angle goes in almost the opposite direction. In this instance the cue is taken from the text and in order to reveal a rainbow of meaning a number of theories are dovetailed with the specific text. In a certain sense it has the text setting the agenda, as was (and is) the case with a classic form of biblical interpretation (cf. Barton 1996, 16). However, here the attempt is not to revive the classic model of Abrams (1953) that has a centred text with the worlds of the author, (social) universe and reader orbiting like satellites around it. Helpful as it may have been, it also served to indicate the huge role the reader plays in determining the outcome of the interpretive process (cf. Freund 1987).

The biblical book under consideration is composed of different text types and thus more than one theoretical point of departure is called for when investigating the bodies in this book. In the case of each individual section (chapter) the aim is to create and partake in a 
dialogue between the world of the text and the world of the reader. Before turning to these individual sections, let us briefly refresh our memories as to the content of the book as a whole. Literary speaking, the book consists of 2 sections: Daniel 1-6 contains well-known stories about (1) refusing defilement by foreign food, (2) a dream about a four-part statue, (3) a story about three men thrown into a fiery furnace, (4) a dream about a huge tree and a king losing his mind, (5) a hand writing weird words on a wall, and a king losing his bladder control, and (6) a story about a man thrown into a lion's pit. With this section of the book most people are quite familiar. The second section of the book (Dan 7-12) is usually described as the visionary part, although chapter 9 perhaps does not meet all the requirements in this respect. In this section we read about (7) a vision of four animals coming up from the sea - the fourth being a real terror, (8) a vision of a ram and a goat, (9) a prayer of supplication, and the last three chapters (10-12) are viewed as a fourth vision pertaining to the future. In the following sections this article will take a closer look at the bodies presented in each of these units.

\section{Daniel 1: An Apt Heading}

Daniel 1 introduces the reader to most of the characters s/he will meet in this book. This chapter is written in Hebrew and corresponds to the last part of the book (Dan 8-12) written in the same language, although unlike the last part of the book it does not contain a vision, but a narrative. The bulk of the narratives are written in Aramaic (Dan 2-6), while the last of the Aramaic chapters (7) does not contain a narrative, but the first of the four visions. Structurally Dan 1 mimics the chiastic manner in which both the Aramaic section (Dan 2-7) and the Hebrew section (Dan 8-12) are structured (Van Deventer 2000, 73).

The first acting body that we meet in Dan 1:1-2 is that of a king. The presence of a royal body in a narrative usually denotes authority (Turner 1997, 18). In this story it is surely the case. We learn that this king, much like a later Roman emperor, "comes" (בו), "besieges" (צור) and "takes" (בור). To be sure, nothing about the king's physique is mentioned. The נתן בידו ("he gave into his hand" - v. 2) does mention a hand, but in this context not much can be made of it. In fact, this technical term transforms the active king into an unwittingly passive recipient of another king (of Judah) along with his temple vessels and people. The introductory story to the book of Daniel exhibits a chiastic structure (Goldingay 1989, 8). The last verse of the chapter (v. 21) links up with the first two and refers the reader to another royal body from a later era.

Between these two markers, we find the central story (vv. 8-16) as well as two more specific introductory sections (vv. 3-7 and vv. 17-20). In the last mentioned sections we meet four Jewish youths and with broad brush strokes the narrator informs us of their training at the foreign royal court. We learn that these youths had to be without any physical blemish (טין כל־מאום) and good looking (טובי מראה). Physical disability and even appearance can disqualify one from being a mere servant, especially at a royal court. An irony here is that the Judean royal "seed" (זרע) becomes royal servants (Fewell 1991, 17). In the past scholars' lengthy comments on this section often stressed the intellectual capability (cf. Porteous 1965, 27; Goldingay 1989, 15-17), which is another requirement for service at the royal court and indicated here by means of hendiatris with משכילים ("insightful"), ידעי ("knowledgeable"), and ("discerning") in v. 4 denoting intellectual attributes. This would suggest that the intellect is more important than the requirements related to physical appearance. If true, it is a classic example of the modernity dualism where the intellect (reason) is rated much higher than issues pertaining to the body (cf. 
Midgley 1997, 54). It should be noted, however, that the strategy employed for the training of the youths has direct bearing on their diet, that is, what goes into their bodies in order to obtain the required results. No specific programme for their intellectual training is given in any detail. The authoritative royal body, itself a sign of the highest human perfection, should be surrounded by similar bodies. The unblemished bodies noted in this introductory chapter are later referred to again in the persecution stories (cf. Dan 3:25; 6:24).

This brings us to the central story in Dan 1 (vv. 8-16). We learn that the future servants were given a diet indeed fit for a king. For most captives such an opportunity seldom presents itself. In the context of the narrative, however, it is indicative of total control over the youths. ${ }^{1}$ While their minds are changed to fit into the new cultural milieu (e.g., new names, new curricula), their bodies must also comply with the new situation. The very first stories in Bible already indicated what an extremely persuasive tool food can be (cf. McKinlay 1999, 75). Over and against the authoritative statement made by the prescriptive diet, initially one and later four of the Jewish youths seek to prove a point of their own. Food and bodily defilement become a battleground for determining who has more authority, in short who actually governs the situation (cf. Fewell 1991, 20).

Over and above such a politically interested interpretation of the text, which in itself is a product of only the last few decades, scholars operating from a historical critical stance pondered the reason for such a decision on the part of the Jewish youths. If the stories are placed somewhere between the second and fourth century B.C.E. (the late Persian, early Greek periods) and they were directed to Jews outside Palestine and the influence sphere of the second temple, such a strictness regarding dietary regulations is not anticipated. However, it is exactly in such a context that we may expect this type of decision when Douglas' (1969) insights are brought to bear on the issue. She (Douglas 1969, 57) states: "[b]y rules of avoidance holiness was given a physical expression in every encounter with the animal kingdom and at every meal." Although she goes on to see the dietary rules as part of a liturgical act "culminating in the sacrifice in the Temple" it stands to reason that in a context where there is no temple, such rules filled that void. In this way the decision of the four young men can be viewed as a means of literally embodying religion. In the process their bodies also become symbols of (political) deviance. They challenge the concept of cultural control imposed by a foreign power. This is of course not a straightforward rejection of all authority over their bodies, because in their decision they are subjecting themselves to another (divine) authority. However, and this is the point, it is their decision that triumphs. And in the narrative world their bodies also triumph. After a ten day test it is their physical appearances that persuade their guard to permanently change their diet (vv. 15-16).

In this introductory story the narrator indicates the role played by the body in religion (and politics) and sets the tone for the following Aramaic section of the book.

\section{The Aramaic Body of the Book (Daniel 2-7)}

The Aramaic section of the book is also structured in a chiastic manner (Lenglet 1972). The outer brackets (Dan 2,7) employ a four-part scheme to refer to coming events. These "prophecies" are ex eventu and reflect more on what happened in the past than on what will happen in the future. In the centre of the chiasm we find two stories (Dan 4, 5) about human hubris as manifested in a foreign ruler. In one story (Dan 4) the ruler repents and his

McKinlay $(1999,74)$ makes a similar remark regarding the food mentioned in Gen 2-3: "The matter of divine control is the crux of the Garden story." 
punishment is revoked, while in the other the ruler is killed (Dan 5). Between the inner and outer components of the chiasm the persecution stories are placed. In Dan 3, three of the Jewish men (excluding Daniel) that were introduced in the first chapter are thrown into a fiery furnace. In Dan 6, Daniel himself is tossed into a lion's pit. In both stories the "punishment" follows on the Jewish characters disobeying a royal degree related to religious worship. In the following investigation of the bodies in the Aramaic section we shall treat them in the textual pairs that form the chiastic pattern.

In Dan 2 history finds embodiment in a huge statue. Although this body takes centre stage in the story, it is introduced as part of a dream that the king has, but which he seemingly cannot remember. His diviners are tasked to reveal both the dream and the interpretation and they are threatened that if they should fail in any way, their bodies will be mutilated, that is dismembered (הדימין יתתעבדוּן) (Dan 2:5). This is a classic example of what Foucault $(1991,8)$ refers to as "the body as the major target of penal repression." In the narrative world this threat serves the rhetorical function of characterization (Goldingay $1989,43)$. The king is thereby polarized vis-à-vis his diviners, including Daniel. The task set by the king is an impossible one and the diviners complain that only the gods not dwelling among the flesh (עם-בשראה) would be able to fulfil such a wish. The king thereupon gives the order that all the diviners be killed, but Daniel steps in to save the day. With divine assistance he reveals to the king and the reader this dream.

This history-embodying statue of the king's dream is quite impressive. It is made of metals decreasing in value as we examine it from the golden head to the iron-and-clay toes. Collins (1993, 162) notes that gigantic (divine) figures appear in ancient Near Eastern dreams, and that history is sometimes represented by a sequence of devaluating metals. However, it is only in Dan 2 where these two elements are apparently combined. The statue represents current and coming earthly kingdoms, but in the end the fate foreseen to befall the diviners befalls the statue - it is utterly destructed and this by means of a single stone exploiting the fatal weakness in its feet (Goldingay 1989, 57). This mysterious stone grows to fill the earth and represents a final kingdom, but it operates without any human impulse (לא בידין). This is interpreted as a kingdom put in place by the same divine power (Dan $2: 44$ ) that also revealed the mysterious dream (Dan 2:28). Although the divine being acts, no physical attributes are mentioned. After the revelation of the dream to the king, the story ends on an ironic note. The easily angered king is depicted laying face down (על-אנפוהי) on the ground, admiring - no in fact worshipping (סגד) his talented servant (Dan 2:46). In Dan 2 then, the relative nature of powerful human institutions and their ultimate submission to a greater "power" is revealed by means of a huge humanlike statue.

Daniel 2 finds its chiastic counterpart in Dan 7 where again a series of four kingdoms is envisaged. However, in this case the symbol of a four-part human statue makes way for four beast-like characters representing earthly kingdoms. In apocalyptic literature earthly rulers are often depicted as animals and thus one cannot read too much into the four beasts. It may be noted though that in this chapter the beasts become more and more fantastic and fear provoking. The first looses the wings it initially had and becomes more human-like: It is put down to stand on two legs and is given a human heart. This beast resembles king Nebuchadnezzar's changed appearance in Dan 4 (cf. the reference to "eagle" [Dan 4:33] and the fact that the king is given an animal heart [Dan 4:16]). The second beast no longer exhibits any human features: It is depicted with three ribs between its bear-like teeth. The third is even scarier: At first it looks like a leopard but then the reader is informed of its four wings and its four heads. The fourth animal is horrific, not only in appearance, but also in actions. The text draws the attention to focus on a specific feature: A horn again with 
human-like features - eyes and a mouth (Dan 7:8). Its mouth speaks great things. Unlike the situation in Dan 2 it is only this last beast that is slain, in fact utterly destroyed (אבד). The graphic depiction of its "punishment" bespeaks a different attitude towards the fourth empire. The animal "bodies" are indicative of a less positive attitude towards foreign powers - most probably due to the same attitude from the side of these powers, and especially that of Antiochus Epiphanes, who venomously persecuted the Jewish populace in Jerusalem during the first quarter of the second century B.C.E. ${ }^{2}$

Daniel 7 also renders other bodies to investigate. The first is that of the divine being depicted as an Ancient of Days (עיק יומין) (Dan 7:9). This is the last anthropomorphic appearance that the deity makes in the Hebrew Bible and his embodiment is a far cry from the active Creator God the reader met in Gen 1. Although in Dan 2, the chiastic complement of Dan 7, God is not embodied, he is active: He gives insight into riddles, reveals hidden things and even sets up and removes kings - albeit behind the scenes. Daniel 7 reveals a different picture: God is not revered for what he does, as in Dan $2,{ }^{3}$ but primarily for what he is - an Ancient of Days. This is another example of what EilbergSchwartz $(1997,47)$ refers to as only a partial conceptualisation of God's body. More detail is given here than in Ezek 1:26-27, but still the divine sex is veiled by the impotent "old man" metaphor.

Linked to Ancient of Days is a man-like figure - the notorious "one like a son of man" (כבר אנשי) (Dan 7:13). This article focuses on the human-like body found in the text and not on the identity of this person (cf. Burkett [2000] for a longer, and Collins [1993, 304-310] for a shorter overview of scholarly opinion in this regard). Here only two things are noted: First, in the text the man-like figure is in every sense the opposite of the four beastly rulers (Hartman and Di Lella 1978, 218), and second, a textual link between this character and the one "like a son of gods" in the persecution story in Dan 3 should be considered. In the latter instance a heavenly character provides protection for three men, who are in a fiery furnace as punishment for their defiance of an earthly ruler. In Dan 7 we find an earthly counterpart "one like a son of man" being revered in a heavenly court after the punishment (and incineration! - Dan 7:11) of an earthly emperor for his defiance of a heavenly ruler (Dan $7: 8,25)$. Although "the sense of alienation from the present order" is basic to especially the historical apocalypses (Collins 1998, 24), it should be noted that the use of body-language draws these fantastical scenes into the earthly realm of every person.

The last character appearing in Dan 2 and 7 is of course Daniel himself. In Dan 2 he is a bold character confronting a harsh king, and in the end the one that the king worships. In Dan 7 the scene has completely changed around. The interpreter of dreams in Dan 2 is now dependant on another intermediary for an interpretation of a night vision. The fearless character in Dan 2 is depicted as a fearful one at the end of the Aramaic section of the book (Dan 7:28). The body of the character Daniel appearing in Dan 2 and 7 respectively before and after a persecution story discloses how persistent persecution leads to pessimism and a reinterpretation of the body.

In Dan 3 a royal decree is issued that a huge statue erected by the king should be worshipped. Those who refuse to conform will be met by a heated response from the king (Dan 3:6). This is an ancient example of what Foucault $(1991,48)$ described as follows: "The right to punish ... is an aspect of the sovereign's right to make war on his enemies,"

Grabbe $(1992,274-285)$ discusses the possible reasons for his conduct.

Fewell (1991) indicates, on basis of the appended doxology to Dan 2 (2:46-49), that Daniel is in fact receiving the reference that God should receive, without any objection on Daniel's part. 
since an offence is in essence an attack on the sovereign. Opposite the caricatured bodies in the narrative, especially those of the authoritative king and his frenzied counsellors, we find three steadfast Jewish men (excluding Daniel) not adhering to the command. The punishment that they are set to incur will not be aimed at correction, which is a judicial goal, but at the annulment in public of their bodies for transgressing the royal order, which is a political goal (cf. Foucault 1991, 47).

The body language used in this chapter centres on what happens (or, actually does not happen) to their bodies. In the midst of the fierce fire (heated 7 times more than required) they are protected through divine intervention (Dan 3:25). The king and his counsellors marvel at the fact that the fire had no power over their bodies. Ironically, they are admitting that they had no power over the bodies of the men - an idea to be taken up again in the last chapter of the book (cf. Collins 1993, 194). Their bodies emerge from the fire intact: The heat could not affect their clothes or their hair - not even the smell of fire clutched their bodies (Dan 3:27). The ethical aim of the story, a characteristic of apocalyptic literature (Collins 1979, 26), is placed in the mouth of the king and refers explicitly to the body, thus linking body and worship (religion): "They gave their bodies so that they should not serve or worship any god except their own" (Dan 3:28 - MT). In a reversal of fortune the bodies of the strong men who threw the three into the fire get incinerated.

Daniel 6, the chiastic counterpart to Dan 3, picks up on the persecution theme. However, this time it is not a group that transgresses a royal degree to worship the king ("request in prayer" - בעה), but a sole individual, namely Daniel. The plot is also different: The king is not the one instigating the new law (cf. Dan 3:10), but the opponents of Daniel. They persuade a less assertive king to issue an edict making him the sole beneficiary of all petitions and supplications for thirty days. Daniel is caught in the act of "kneeling on his knees" (ברףך על־ברכוהי) and despite the king's attempts at reversing his fate (Dan 6:15) Daniel is thrown into the lions' pit. The king expresses his remorse at what happened by spending the night denying his body any food. He does not realize that, again through divine intervention (Dan 6:21), the lions are doing the same. The next day, when Daniel is brought up out of the pit his body does not bear any signs of injury (Dan 6:24). Again, those responsible for Daniel's ordeal, together with their families, are thrown into the pit. A similar reversal of fortune than in Dan 3 takes place - the lions mutilate their bodies. In the real world such events do not take place, but Dan 3 and 6 are not first and foremost situated in a real world. These chapters contain a promise to persecuted bodies that will be worked out towards the end of the book.

In the centre of the chiasm formed by the Aramaic chapters of the book there are two narratives dealing with human hubris. In both bodily imageries abound. In Dan 4 the body of a king is transformed into the body of a beast after he does not adhere to a warning presented to him in the form of a dream. Such a transformation of a royal body implies grave and disorderly consequences for society as a whole (Turner 1997, 18). This transformation goes beyond the external body and involves a change of heart - the king receives an animal heart (Dan 4:16). Thus, from an Old Testament perspective, the "focal point of moral action, the seat of intelligence and wisdom" is removed (Ware 1997, 100). Above it was noted how this transformation hints at the animal imagery employed later in the book (Dan 7). What is important from both the perspective of the foreign ruler and the Jewish subjects is that the process can be turned around. The ruler who recognizes his wrongdoing in challenging a higher authority can be reinstated - he receives back his humbled human heart. 
In Dan 5 the opposite happens: A ruler who refuses to adhere to a higher authority is removed. In this story a foreign king misuses the temple vessels taken from Jerusalem while wining and dining with his concubines (Dan 5:3). Suddenly a severed bodily part appears and writes the king a short note on a wall. Whereas in Dan 4 the king loses control over his body in becoming a beast, the king in Dan 5 loses control over his bodily functions. The foreign ruler who tried his hand at controlling the bodies of his Jewish subjects in the persecution stories (Dan 3 and 6) is depicted here as not able to control his own body. Although it differs in degree both stories refers to the social embarrassment accompanying such a loss of control. The reader is ingeniously informed that the "knots of his [the kings] loins were loosened" (קטרי הרצה משתרין) - Dan 5:6) - an euphemism referring to uncontrollable excretions from the loin region (cf. Brenner 1994, 49-50). Similar to Dan 4 where the transformation from human to animal is described in detail, Dan 5 makes the bodily reaction of the king exceedingly explicit. Unlike Dan 4 however, the king in Dan 5 does not get another chance - his life ends before the end of the story.

Right in centre of the chiasm in the Aramaic part of the book of Daniel the bodies of foreign rulers take centre stage. What happens to their bodies is perhaps less of a warning to those rulers than a source of comfort and even entertainment for those over whose bodies they rule (cf. Wolters 1991). These powerful rulers are depicted as ordinary people who may even lose control over their bodies.

\section{The Hebrew Body of the Book (Daniel 8-12)}

After Dan 7 body language becomes rare and where it is employed it is almost exclusively used as regards the visionary Daniel and indicates the tremendous strain that is caused by the visions he sees. He is not only a passive observer, but what he sees impacts on his body (cf. Dan 8:27).

In Dan 8 a ram and a goat is representing the kings of Persia and Greece respectively. Their embodiment as animals need not concern us over and above what was noted on Dan 7 and the beasts appearing there. Daniel 8 and 10-12 are both ex eventu visions pertaining to "future events" although the last part of Dan 11 (cf. vv. 40-45) contains an (erroneous) attempt at predicting real future events (Collins 1993, 388). In each section the visionary Daniel is exhausted and in want, not only of understanding, but of bodily support (cf. 8:18; 10:8-10, 16-18). The strength that is provided by a heavenly being only helps insofar as the visionary using it to lament his dreadful bodily condition. Of the self-assured spokesman we met in Dan 1 very little is left.

The absence of bodies in the last part of the book can be read against the persecution of the Jews by Antiochus Epiphanes and the presence of dead bodies that it caused. In the real world persecution leads to death - the human body can bear only a certain amount. Human bodies cannot survive a fiery furnace, or being thrown to lions. Faced with these facts in the real world the optimism of the earlier stories have to make way for a more pessimistic view on the possibility of deliverance from persecution. This is the setting for the climax of the book of Daniel and perhaps the Old Testament as such. In an unprecedented developmental leap in Old Testament religion the persecuted body also becomes a means of subversion in this instance undermining the dire result of persecution. Death itself is defied and with it any attempt by political powers at subverting people by means of the gravest bodily punishments. This defiance of death does not relate to the metaphysical Greek idea of the immortality of the soul (Ware 1997, 91). The body itself is to be resurrected (Dan 12:2)! The scorned and persecuted earthly body becomes like an exalted celestial body (Dan 
12:3). As Louth $(1997,128)$ citing Bynum states: "If corruption or fragmentation or division of the body ... is the central threat, resurrection ... is the central victory."

\section{Conclusion}

Bodies in the book of Daniel have come a long way. From foreign bodies at the Babylonian court (Dan 1:3) they have progressed to celestial bodies (Dan 12:3). Reading the book of Daniel from the perspective of the body revealed among others how bodies were used as means of subverting oppressive measures aimed against them. In fact, they countered politically enforced attempts at annulment.

This article presents an attempt at reading the book of Daniel from the perspective of the body. Such a reading strategy uncovered in this instance a number of prospects of which a few were highlighted. It seems as if especially apocalyptic literature, perhaps owing to its social setting, has a lot to offer as regards the rhetoric of body politics and religious discourse.

\section{BIBLIOGRAPHY}

Abrams, MH 1953. The Mirror and the Lamp: Romantic Theory and the Critical Tradition. London: Oxford University Press.

Adam, AKM 1995. What is Postmodern Biblical Criticism? Minneapolis: Fortress.

Barton, J 1996. Reading the Old Testament. Method in Biblical Study. Rev. and enl. ed. Louisville: Westminster John Knox.

Bible and Culture Collective 1995. The Postmodern Bible. New Haven: Yale University Press.

Brenner, A 1994. Who's Afraid of Feminist Criticism? Who's Afraid of Biblical Humour? The Case of the Obtuse Foreign Ruler in the Hebrew Bible. Journal for the Study of the Old Testament 63:38-54.

Burkett, D 2000. The Son of Man Debate: A History and Evaluation. Cambridge: Cambridge University Press.

Collins, JJ 1998. The Apocalyptic Imagination. An Introduction to Jewish Apocalyptic Literature. $2^{\text {nd }}$ ed. Grand Rapids: William B Eerdmans Publishing Company.

---- 1993. A Commentary on the Book of Daniel. Hermeneia. Minneapolis: Fortress.

--- 1979. The Jewish Apocalypses. Pages 21-59 in Apocalypse. The Morphology of a Genre. Edited by JJ Collins. Atlanta: Scholars Press.

Douglas, M 1969. Purity and Danger. An Analysis of Concepts of Pollution and Taboo. Second Impression with Corrections. London: Routledge \& Kegan Paul.

Eilberg-Schwartz, H 1997. The Problem of the Body for the People of the Book. Pages 3455 in Reading Bibles, Writing Bodies. Identity and the Book. Edited by TK Beal and DM Gunn. London: Routledge.

Fewell, DN 1991. Circle of Sovereignty. Plotting Politics in the Book of Daniel. Nashville: Abingdon Press.

Foucault, M 1991. Discipline and Punish. The Birth of the Prison. Translated by A Sheridan. London: Penguin.

Freund, E 1987. The Return of the Reader. Reader-Response Criticism. London: Methuen. 
Goldingay, J 1989. Daniel. Word Biblical Commentary 30. Dallas: Word Books.

Grabbe, LL 1992. Judaism from Cyrus to Hadrian. London: SCM Press.

Hartman, LF and Di Lella, AA 1978. The Book of Daniel. Anchor Bible. New York: Doubleday.

Lenglet, A 1972. La Structure Littéraire Daniel 2-7. Biblica 53:69-90.

Louth, A 1997. The Body in Western Catholic Christianity. Pages 111-130 in Religion and the Body. Edited by S. Coakley. Cambridge: Cambridge University Press.

McKinlay, JE 1999. To Eat or not to Eat: Where is Wisdom in this Choice? Pages 73-84 in Food and Drink in the Biblical Worlds. Edited by A. Brenner. Atlanta: Society of Biblical Literature.

Midgley, M 1997. The Soul's Successors: Philosophy and the "Body." Pages 53-68 in Religion and the Body. Edited by S. Coakley. Cambridge: Cambridge University Press.

Porteous, NW 1965. Daniel. Old Testament Library. London: SCM Press.

Turner, BS 1997. The Body in Western Society: Social Theory and its Perspectives. Pages 15-41 in Religion and the Body. Edited by S. Coakley. Cambridge: Cambridge University Press.

Van Deventer, HJM 2000. The End of the End. Or, What is the Deuteronomist (still) doing in Daniel? Pages 62-75 in The Deuteronomistic History and the Prophets. Edited by JC de Moor and HF van Rooy. Leiden: Brill.

Ware, W 1997. "My Helper and my Enemy": The Body in Greek Christianity. Pages 90110 in Religion and the Body. Edited by S. Coakley. Cambridge: Cambridge University Press.

Wolters, A 1991. Untying the King's Knots: Physiology and Wordplay in Daniel 5. Journal of Biblical Literature 110(1):117-122. 